\title{
Application of the concept of collective dominance in the Russian competition law: challenges and solutions
}

\author{
Igor Bashlakov-Nikolaev ${ }^{1, *}$ and Sergey Maximov ${ }^{2}$ \\ ${ }^{1}$ Moscow Region State University, 10A, Radio str., 105005, Moscow, Russia \\ ${ }^{2}$ Institute of problems of development of science of the Russian academy, 32, Nauknakhimovskiya \\ Pr., 117218, Moscow, Russia
}

\begin{abstract}
The Russian competition law does not include the definition of the concept of collective dominance, and the notion of this institution itself contains many gaps. The indicated disadvantages of statutory regulation and simplified approaches of the Federal Antimonopoly Service, which became possible due to the formal approach, have led to the formation of controversial law enforcement practice by the antimonopoly authority and courts. The article presents the analysis of legal regulation, as well as the law enforcement practice, and proposition on solutions to the stated problems.
\end{abstract}

\section{Introduction}

Due to the high requirements for proving the existence of a cartel and concerted actions that restrict competition, the law enforcement agency considers the collective dominance in an oligopolistic market to be a tacit collusion that does not require special proof [1]. The scientific literature indicates that when there is an allegation of abuse of a dominant position in collective dominance, the antimonopoly authority does not examine the relations between its participants and the individual behavior of economic units is evaluated independently of behavior of other participants of the dominance [2]. Based on the requirements of the Russian competition law, the collective dominance is established by determining quantitative and qualitative conditions for dominance. However, the considered conditions that are contained in the Russian competition law do not characterize the actions and market power of economic units that are part of the collective dominance, but the commodity market. This approach, which involves establishing collective dominance on the basis of objective data on commodity markets without determining the subjective behavior of the participants of collective dominance, leading to each participant of collective dominance separately achieving the market power, that allows to have a onesided impact on commodity's circulation in the commodity market, has signs of strict liability.

In economic theory, collective dominance is always associated with the cooperation between economic units for the purpose of coordination of actions with a view to limiting

*Corresponding author: bniv@list.ru 
competition and "punishing" "unruly" competitors [3] (competitors who are not willing to follow a common strategy). The cooperation allows to realize the benefits available in the oligopolistic market, enabling to establish stable "relationships" between the participants of collective dominance, which could lead to the achievement of the market power. Moreover, the cooperation enables members of the collective dominance to freely exchange the information on the commodity's circulation in the commodity market, which is a legal condition for establishing the collective dominance. In addition, the cooperation enables the penalty for those who refuse to follow the common strategy of collective dominance, that leads to the achievement of the market power through the restriction of competition between the participants of collective dominance.

In law enforcement practice, the institution of collective dominance has been regarded as a more effective and less time-consuming method of proving anticompetitive agreements, despite the fact that oligopolistic markets are characterized by a tough and usually unrelenting competition that is rarely found in other markets, and any serious mistake made by a competitor is used to remove them from the market [4]. This replacement is justified in the context of law enforcement of the regulator, which is interested in procedural economy, including the economy of obtaining evidence of a competition restriction through cooperation between the participants of collective dominance.

It should be noted that the Russian competition law does not specify the cases which the collective dominance could be applied to. Currently, by default, the legislation allows the application of this institution to cases of abuse of a dominant position in the commodity market, as well as economic concentration control, and cases of forced separation of economic units that systematically restrict competition in the commodity market. Firstly, such scope of application of collective dominance distinguishes the Russian regulation from the one of the European Union, in which it is limited only to cases of control of economic concentration. And, secondly, with the existing regulation and the lack of description of the mechanism for the emergence of the market power of economic units with a market share of $8-35 \%$ and unreasonable presumption of such phenomenon (the market power), it is hardly possible to consider the regulator's allegation of abuse of the market power in relation to a particular economic unit to be reasonable, if the emergence of the market power is not specified, and it is only based on the fact that the market power is explained by the unit's operation in an oligopolistic market, which is actually characterized by tough competition.

In addition, the legal regulation of the concept of a dominant position in general, as well as of the concept of collective dominance in the Russian competition law does not regulate the issue as to whether it is possible to simultaneously establish collective and single firm dominance, whether the establishment of single firm abuse of a collective dominant position is possible, as well as the mechanism for the emergence of the market power of one of the participants of collective dominance.

All of the above indicates the numerous gaps in the regulation of the legal institution of collective dominance in the competition law of the Russian Federation and the uncertainty that arises in the process of enforcement by antimonopoly authorities and courts.

In the Russian competition law, the institution of collective dominance is described in the norms of Parts 1 and 3 Article 5 of Federal Law No. 135-FZ of July 26, 2006 "On Protection of Competition" (hereinafter - the Law on Protection of Competition).

The analysis demonstrates that the content of the institution of collective dominance (the dominance of several economic units), which is contained and used in Part 1 Article 5 of the Law on Protection of Competition, is specified and disclosed in Part 3 of this Article through the same features (conditions) that denote the content of the concept of a dominant position of an economic unit (group of persons) or, the so-called single firm dominance. 
The information presented above allows to conclude that the legislator does not view any significant differences between the concept of market dominance of an economic unit (group of persons) and a simultaneous dominance of a set of independent economic units.

\section{Materials and methods}

The gaps in the legal regulation of the institution of collective dominance give rise to a controversial and irregular practice of law enforcement by both the regulator and courts. With a formal approach, this practice generates mistakes that reduce the effectiveness of the regulatory influence on commodity markets. On the one hand, the research at hand provides the analysis of the regulatory material, and, on the other hand, the law enforcement practice and opinions of scientists. The results obtained suggest that it is not possible to fill the gaps in regulation by adjusting the practice of law enforcement and that it is necessary to make legislative amendments to the norms that regulate the institution of collective dominance in the Russian competition law.

It appears that problems in the regulation and application of the concept of collective dominance in the Russian competition law are associated with the adoption of this legal institution as a result of borrowing of the European approach to antimonopoly regulation. In accordance with Article 102 (ex Article 82) of the Treaty on the Functioning of the European Union [5] (hereinafter referred to as the EU Treaty, TFEU), any abuse by one or more undertakings of a dominant position within the internal market or in a substantial part of it shall be prohibited as incompatible with the internal market in so far as it may affect trade between Member States.

In this regard, it seems necessary to consider what is understood by the concept of collective dominance in the EU Treaty.

The Norwegian researchers Ronny Gjendemsjø, Erling J. Hjelmeng, Lars sørgard point out that "while the concept of collective dominance has developed in line with a sound economic approach focusing on coordinated effects, no genuine concept of abuse in such situations has been established" [6]. According to them, this concept has been closely linked to the abuse concept in single dominance cases, and Article 102 of the EU Treaty should be adapted to the particular challenges posed by collective dominance and primarily focus on conduct having as its object or effect the strengthening of the collective dominant position by reinforcing the oligopolistic interdependence and the tightening of the oligopoly. The authors consider the weakness in this approach to be that single firm and collective dominance are based on various factors, namely, unilateral and coordinated effects, which may occur in different ways. Traditional single firm abuses are exclusionary conduct, and conduct with coordinated effects in an oligopoly "excludes" rivalry among the collective dominant firms.

According to the authors, law enforcement practice on abuse of collective dominance did not concern typical oligopolies. There is no discussion of the concept of abuse of a dominant position in the judgments. In addition, the courts used the same statement for collective dominance as well as for single firm dominance (Cases C-393/92, T-228/97).

In the authors' opinion, the new approach implies that the concept of collective dominant position which arises in oligopolies should be based on the fact that the negative effect of dominance may be strengthened by restricting or eliminating "internal" competitive pressure of collective domination, similar to how eliminating external competitive pressure may strengthen a single firm dominant position.

Felix E. Mezzanotte [7] points out that Article 102 TFEU might prohibit the abuse of collective dominance (the abusive conduct of tacitly colluding firms), but questions the ability of the antimonopoly authority to enforce this law due to the difficult problem of distinguishing tacit collusion from unconscious parallelism or undetected overt 
collusion. According to F. Mezzanotte, the problem cannot be resolved by establishing the typical conditions drawn from case law. Abuse of collective dominance may not even be plausible in real world. A problem of detection and costly error restricts dramatically the ability of the European Commission to combat collective dominance as a form of tacit collusion by using Article 102 TFEU. And if carried out, such a policy would be misguided.

A different approach to the application of the concept of abuse of collective dominance to behavior by interdependent companies in a concentrated market was proposed in the dissertation by Van De Scheur, Sebastian B.W., who called abuse of collective dominance under Article 102 TFEU a "blind spot" in European competition law [8]. According to the researcher, the focus of enforcing Article 102 TFEU should not be on trying to catch tacit collusion or supracompetitive oligopoly prices, but on practices by which one or more incumbents exclude outsiders (newcomers, innovators and fringe competitors) to the benefit of the incumbent 'insiders' of the oligopolistic equilibrium. The objective concept of abuse as used in cases of single dominance could not be applied to the assessment of abuse in cases of collective dominance, since in the latter case a causal link between market power and abuse should be demonstrated.

The Chinese antimonopoly experts Zhan Hao, Song Ying and Tian Chen [9] believe that one of the significant preconditions for determining collective dominance is the existence of a strong link between separate undertakings, stemming from the nature and terms of an agreement between the undertakings in question, or from the way in which it is implemented, provided that the agreement leads the undertakings in question to present themselves or act together as a collective entity.

A key difference of the conclusion of the necessity of establishment of cooperation between the participants of collective dominance that ensures the achievement of market power by every participant of the collective dominance as well as of the previously presented expert opinions from the position that could be based on a formal interpretation of the competition law, is that in order to determine the collective dominance it is necessary to establish the cooperation that restricts competition, rather than conditions for collective dominance, which is included in the competition law.

Despite the fact that the provisions of Russian competition law in the context of collective dominance were formulated under the influence of European Union law, their correct interpretation and application in the interests of maintaining and developing competition in oligopolistic markets could not be ensured solely through the explanations by the regulator or by the Supreme Court and require a legislative definition.

This is explained by the fact that, in the Russian competition law, it is not possible to fill the gaps in the legal norms by issuing explanations, since the antimonopoly regulator does not have the authority to do so. In the Russian competition law, the antimonopoly body has the authority to give explanations in respect of the application by it of the anti-monopoly legislation. In other words, the antimonopoly regulator has the authority to clarify why and on what basis certain regulatory decisions are made.

Moreover, the Supreme Court in the Russian Federation does not create new legal norms and does not have the authority to fill in gaps in legal regulation. The Supreme Court of the Russian Federation considers the materials acquired through analysis and generalisation of judicial practice and gives clarifications on issues of judicial practice to the courts in order to ensure the uniform application of legislation of the Russian Federation.

However, the antimonopoly legislation of the Russian Federation does not take into account the fact that in cases in which abuse of a collective dominant position is associated with a refusal to make a contract or the imposition of unfavorable contract terms and 
conditions, the establishment of dominance and abuse without considering the behavior of all collectively (jointly) dominant units is not possible [10].

According to the author of the research at hand, the definition of abuse of a dominant position in cases of collective dominance should include an obligatory feature, namely, the jointness of behavior of participants of collective dominance, which might lead to restriction of competition, provided that there are no signs of anticompetitive agreements or concerted actions. Furthermore, in this case, jointness does not refer to abstract parallelism. Jointness should be associated with the anticompetitive agreement between participants of collective dominance. The anticompetitive agreement within a group of dominant firms could lead to the emergence of the market power of an economic unit the market share of which is so small that it could not allow it to achieve the market power individually (a single firm dominant position). This refers to economic units that occupy a share of 8 to 35 percent of the commodity market.

Otherwise, the implemented formal approach would predetermine a simplified approach, when in the presence of the conditions for collective dominance for the commodity market contained in the competition law, would be interpreted by the regulator as collective dominance in the commodity market without considering whether in fact an economic unit has the capacity to one-sidedly impact the commodity's circulation in the specified commodity market.

The implementation of this approach that implies the establishment of cooperation between the participants of collective dominance indicating a anticompetitive agreement within the collectively dominant units under conditions of digital economy and the inevitable growth of pressure on the antimonopoly body would require the improvement of the analysis of oligopolistic markets based on mathematical models [11]. This approach would allow distinguishing between the random coincidence of economic behavior of participants in oligopolistic markets and jointness of actions different from anticompetitive agreements and concerted actions in the commodity market.

In the context of filling the gaps in law enforcement that create uncertainty and allow the use of a formal approach to establishment of collective dominance, the law must to specify which cases the institution of collective dominance could be applied to, as well as to establish a rule according to which, in case of single dominance, it is not allowed to establish collective dominance and single firm's abuse of a collective dominant position.

In addition, it is necessary to legislatively clarify the purpose of antimonopoly regulation given the already emerging shift from the model of predominant protection of competition employing legal liability for antimonopoly violations to the model of legal support of competition, based on the prioritized measures of prevention of violations and the development.

\section{Results}

In order for the institution of collective dominance as an institution of dominance of several economic units to be separate from the institution of single firm dominance, the Law on Protection of Competition need to provide a description of how a group of independent economic units of collective dominance jointly and each participant of collective dominance individually exert a critical influence upon the general conditions of a commodity's circulation in the appropriate commodity market and (or) to remove other economic units from this commodity market and (or) to impede access to this commodity market of other economic units (which can lead to restriction of competition), as a result of joint activities whereby behavior of each participant of the group depends on behavior of other participants of the same group. 
Otherwise, this group would not differ in any way from a random group of economic units operating in the same market.

Therefore, collective (multi-subject) dominance in a market creates objective prerequisites for abuse of a dominant position (which can lead to restriction of competition) when it is possible for one or more economic units of collective dominance to exert a critical influence upon the general conditions of a commodity's circulation in the appropriate commodity market and (or) to remove other economic units from this commodity market and (or) to impede access to this commodity market of other economic units as a result of cooperation between such economic units, and not due to the formal presence of conditions of a dominant position specified in Part 3 Article 5 of the Law on Protection of Competition.

This cooperation between the participants of collective dominance should lead to restriction of competition due to the collaboration of a group of economic units, and not as a result of the fact that the sum of the market shares of the largest economic units would indicate that the market meets the objective conditions described in the conditions for establishing a collective dominant position contained in the competition law. The cooperation between such economic units is crucial for the achievement of the effect of the arithmetic sum of their market power.

\section{Discussion}

If there are several economic units on the commodity market, competition in the market may be restricted by concluding anticompetitive agreements, implementing concerted actions, and abusing a dominant position.

Moreover, it is possible to abuse both a single firm dominant position and a collective dominant position.

In order to create certainty in law enforcement, it is necessary to improve legal regulation in terms of clarifying the legal rules regulating cases in which single firm dominance or collective dominance is determined [12].

In addition, in order to increase the efficiency of law enforcement and ensure the protection of the rights and legitimate interests of economic units in the future, by clarifying legal norms, it will be necessary to separate the cases of application of the institution of collective dominance and cases of application of rules of cartel agreements on the basis of a clear establishment of rights of legal institutions, rather than on the basis of the principle of procedural economy.

\section{Conclusions}

The law on protection of competition does not establish the procedural aspects of the emergence and operation of collective dominance. It is limited to the description of the structural requirements for the oligopolistic market, as well as the share sizes of economic units.

In the Russian competition law, illegal anticompetitive conduct of economic units in the commodity market is covered by anticompetitive agreements, concerted actions and coordination, however, in the case of collective dominance and abuse of collective dominance, illegal conduct is not provided for. Otherwise, it would repeat anticompetitive agreements and concerted actions.

The implemented concept of collective dominance is not established by law. It exists only in the scientific literature and the law enforcement practice. 
The implemented concept of collective dominance enshrines the logical error of the "structure" of the market as the basis for collective dominance instead of the conditions, established in the competition law, making it possible for an economic unit to unilaterally influence the commodity's circulation in the commodity market, to impede access of economic units to the commodity market or to remove them from the commodity market.

The Russian competition law allows simultaneous application of single firm and collective dominance institutions to the same commodity market, despite the fact that the commodity market could not simultaneously be in two different states of monopoly and oligopoly.

The Russian competition law allows for the establishment of single firm abuse of a collective dominant position, which leads to the possibility of holding an economic unit with a market share of $8 \%$ and more liable.

The Russian competition law does not regulate the issues of interinfluence of collectively dominant economic units for the institution of collective dominance. In addition, in economic theory, this influence justifies the emergence of the institution of collective dominance and explains the mechanism of strengthening the market power of the participants of collective dominance. On the grounds that the economic mechanism of creating collective dominance based on cooperation of economic units from among the participants of the group of dominant firms has not been included in the norms of the competition law and is ignored when the antimonopoly authority establishes collective dominance, the institution of collective dominance as a legal institution cannot be considered to be statutory to the extent that legal norms are.

In the Russian competition law, the legal institution of collective dominance is a structure that defines a formal approach to law enforcement. It does not require a deep analysis of a commodity market situation and simplifies the antimonopoly authority's regulating influence on the oligopolistic market.

The elimination of gaps and uncertainties in the legal regulation of the institution of collective dominance in the Russian competition law cannot be carried out through the formation of regulatory clarifications. It should be conducted by changing the statutory regulation, that is introducing amendments to the Law on Protection of Competition.

\section{References}

1. S.B. Avdasheva, N.B. Dzagurova, P.V. Kriuchkova, G.F. Iusupova, Razvitie $i$ primenenie antimonopol'nogo zakonodatel'stva $v$ Rossii: po puti dostizhenii $i$ zabluzhdenii (MAKS Press, 2011)

2. I.V. Kniazeva, S.N. Chirikhin, Aktual'nye voprosy provedeniia analiza sostoianiia konkurentsii na tovarnykh rynkakh (metodologicheskii kommentarii). Monografiia (Novosibirsk, Izd-vo NGTU, 2018)

3. A.E. Shastitko, Rynochnaia vlast' kollektivno dominiruiushchikh kompanii v kontekste primeneniia antimonopol'nogo zakonodatel'stva, https://archive.econ.msu.ru/ext/lib/Category/x0c/x73/3187/file/2010-2-2-5Shastitko\%20A_E.pdf

4. E.Iu. Borzilo, Antimonopol'nye riski predprinimatel'skoi deiatel'nosti. Nauchnoprakticheskoe rukovodstvo (M., Statut, 2014)

5. Dogovor o funktsionirovanii Evropeiskogo Soiuza (SPS «Konsul'tant-Plius»)

6. R. Gjendemsjø, E.J. Hjelmeng, L. Sørgard, World Competition 3, 355-371 (2013) https://www.kluwerlawonline.com/abstract.php\%3Farea\%3DJournals\%26id\%3DWOC O2013029\&prev $=$ search 
7. F.E. Mezzanotte, World Competition 33(1) (2010)

8. Kluwer Law International $B V$ (The Netherlands) https://www.researchgate.net/profile/Felix_Mezzanotte

9. Van De Scheur, B.W. Sebastian, Oligopoly behaviour as abuse of collective dominance in EU competition law (Florence: European University Institute, 2013) http://hdl.handle.net/1814/28057

10. http://www.anjielaw.com/en/uploads/soft/171010/1-1G0101G146.pdf

11. I.V. Bashlakov-Nikolaev, Rossiiskii zhurnal pravovykh issledovaniia 3, 142 (2018)

12. Rossiiskoe konkurentnoe pravo i ekonomika 1, 7 (2019) 